\title{
Perbedaan kadar glukosa darah puasa pasien diabetes melitus berdasarkan pengetahuan gizi, sikap dan tindakan di poli penyakit dalam rumah sakit islam jakarta
}

\begin{abstract}
Ahmad Syauqy ${ }^{1}$
ABSTRACT

Background: Inappropriate eating behavior can cause blood glucose level of diabetes mellitus patients to increase. The behavior is divided into three domains. They are knowledge, attitude, and action.

Objective: This research was an analytic descriptive research with cross-sectional approach. The sample consisted of 50 respondents. They were diabetes mellitus patients having blood glucose level checking in Internist Polyclinic in Rumah Sakit Islam Jakarta (Jakarta Islamic Hospital). Knowledge about nutrition was measured based on indicator of diabetes disease definition, principle, and dietary restriction, food supplement, and activity or exercise; the level of attitude was measured based on diabetes checking indicator, activity/exercise, diet awareness, food ingredients and the amount of portion; level of action was measured based on indicator of food/drink selection, eating habit, eating schedule, activity/exercise, and food supplement. One Way Anova test was applied in order to answer research question.

Results: There were 12 respondents (24\%) lacking of knowledge about nutrition, 14 respondents (28\%) not having really good attitude, 8 respondents (16\%) having less action. On the average blood glucose was different according to knowledge level $(F$ $=4.448 ; p=0.017)$, attitude $(F=3.930 ; p=0.026)$ and action $(F=3.427 ; p=0.041)$.

Conclusion: There is significant difference in blood glucose level based on knowledge about nutrition, attitude, and behavior to patients with type 2 diabetes mellitus in Rumah Sakit Islam Jakarta (Jakarta Islamic Hospital). Research about the effect of counselling about nutrition on patients' behavior is needed so that the success of dietitien can be recognized.
\end{abstract}

Key words: knowledge about nutrition, attitude, action, blood glucose level, diabetes mellitus, nutrition and dietetic polyclinic

\begin{abstract}
ABSTRAK
Latar belakang :Perilaku makan yang tidak tepat dapat menyebabkan meningkatnya kadar glukosa darah penderita diabetes. Perilaku dibagi menjadi tiga domain yaitu pengetahuan, sikap dan tindakan.

Tujuan penelitian :Melihat perbedaan kadar glukosa darah berdasarkan pengetahuan gizi, sikap dan tindakan pasien diabetes melitus tipe 2.

Metode analisis : Jenis penelitian ini adalah penelitian yang bersifat deskriptif analitik dengan pendekatan crosssectional. Sampel sebanyak 50 responden, dalam penelitian ini adalah pasien diabetes melitus yang menjalani pemeriksaan kadar glukosa darah di Poli Penyakit Dalam Rumah Sakit Islam Jakarta. Pengetahuan gizi diukur berdasarkan indikator pengertian penyakit diabetes, prinsip dan syarat diet, penukar bahan makanan dan aktivitas atau olahraga; tingkat sikap diukur berdasarkan indicator pemeriksaan penyakit diabetes, aktifitas/olahraga, kesadaran diet, bahan makanan dan jumlah porsi; tingkat tindakan diukur berdasarkan indikator pemilihan makanan/minuman, kebiasaan makan, jadwal makan, aktifitas/olahraga dan bahan makanan penukar. Pengujian One Way Anova digunakan untuk menjawab pertanyaan penelitian.

Hasil :Sebanyak 12 responden (24\%) memiliki pengetahuan gizi kurang, 14 responden (28\%) memiliki sikap yang kurang baik, 8 responden (16\%) memiliki tindakan kurang. Rata - rata glukosa darah berbeda menurut tingkat pengetahuan $(F=4,448 ; p$ =0,017), $\operatorname{sikap}(F=3,930 ; p=0,026)$ dan tindakan $(F=3,427 ; p=0,041)$.

Simpulan :Ada perbedaan bermakna kadar glukosa darah berdasarkan pengetahuan gizi, sikap dan perilaku terhadap pasien dengan diabetes mellitus tipe 2 di Rumah Sakit Islam Jakarta. Diperlukan penelitian tentang pengaruh konseling gizi terhadap perilaku pasien agar dapat mengetahui keberhasilan Dietisien.
\end{abstract}

Kata kunci : Pengetahuan gizi, sikap, tindakan, kadar glukosa darah, diabetes mellitus, poli gizi rawat jalan

\section{PENDAHULUAN}

Masalah kesehatan dipengaruhi oleh banyak faktor, diantaranya pola hidup, pola makan dan kemajuan teknologi. Teknologi banyak membantu manusia, mengganti tenaga manusia dengan mesin sehingga manusia kurang aktif bergerak. Hal ini

Jurusan Gizi Fakultas Kedokteran Universitas
Diponegoro

memberikan kontribusi negatif terhadap kesehatan termasuk peningkatan penyakit degeneratif. Salah satu penyakit degeneratif adalah diabetes melitus. (Rimbawan dkk, 2004).

Diabetes mellitus (DM) adalah penyakit metabolik yang berlangsung kronik progresif, dengan gejala hiperglikemi yang disebabkan oleh gangguan sekresi insulin, gangguan kerja insulin, atau keduanya. 2,3 Data mengenai epidiomiologi penyakit diabetes mellitus telah mengalami peningkatan dari tahun ke 
tahun. Jumlah penderita diabetes melitus di dunia dari 110,4 juta pada tahun 1994 melonjak 1,5 kali lipat (175,4 juta) pada tahun 2000 dan melonjak dua kali lipat (239,3 juta) pada tahun $2010 .{ }^{4}$

Diabetes melitus disebut juga penyakit metabolisme kronik, yang pengelolaannya perlu dilaksanakan secara holistik dan pemeliharaan mandiri seumur hidup. Dengan pengelolaan yang baik diyakini bahwa akan terpelihara kualitas hidup pasien yang optimal dan terhindar dari berbagai komplikasi kronik diabetes. Salah satu pilar utama pengelolaan diabetes adalah perencanaan makan. Perencanan makan yang baik adalah terapi gizi yang mengikuti prinsip $3 \mathrm{~J}$ yaitu tepat jumlah, jenis dan jadwal. ${ }^{5}$ Dengan melakukan perencanaan makan diharapkan diabetisi dapat mencapai dan mempertahankan kadar glukosa darah. Untuk itu diperlukan suatu perilaku yang sesuai dari diabetisi untuk dapat memelihara atau mengendalikan diabetesnya. ${ }^{6}$ Perilaku dipengaruhi oleh beberapa faktor yaitu pengetahuan, sikap dan tindakan. Perilaku gizi, makanan dan minuman, dapat memelihara serta meningkatkan kesehatan seseorang, tetapi sebaliknya dapat menjadi penyebab menurunnya kesehatan seseorang, bahkan dapat mendatangkan penyakit. Hal ini tergantung pada perilaku orang terhadap makanan dan minuman tersebut. ${ }^{7}$ Pengamatan (observasi) adalah cara untuk mengukur perilaku. Namun dapat juga dilakukan melalui wawancara dengan pendekatan recall atau mengingat kembali perilaku gizi yang telah dilakukan oleh responden beberapa waktu yang lalu. ${ }^{7}$

Glukosa darah dipengaruhi oleh beberapa faktor, antara lain faktor resiko atau faktor pencetus misalnya, adanya infeksi virus, kegemukan, perilaku makan yang salah, obat - obatan, proses menua, stress dan lain - lain. Diet tetap merupakan pengobatan yang utama pada penatalaksanaan diabetes, terutama pada DM tipe 2. Peran diet dapat mengontrol kadar glukosa darah pasien. Diet disini dapat diartikan sebagai perilaku gizi pasien diabetes. ${ }^{6}$

Rumah Sakit Islam Jakarta merupakan rumah sakit swasta dibawah naungan Badan Pengurus Harian Rumah Sakit Islam Jakarta dalam payung organisasi islam Muhammadiyah. Rumah sakit ini melayani pasien rawat inap dan rawat jalan dengan segala jenis penyakit, termasuk diabetes melitus. Sehubungan belum adanya penelitian atau informasi tentang perilaku gizi pada pasien diabetes disana, maka peneliti tertarik untuk melihat perbedaan kadar glukosa darah puasa berdasarkan pengetahuan, sikap dan tindakan dengan kadar glukosa darah puasa pada pasien diabetes melitus di rumah sakit tersebut.

\section{METODE PENELITIAN}

Penelitian dilaksanakan di Rumah Sakit Islam Jakarta pada bulan Juli tahun 2008. Penelitian ini merupakan penelitian deskripsi analitik yang dengan rancangan penelitian menggunakan Cross Sectional yang pengukurannya dilakukan dalam satu waktu.

Populasi penelitian ini adalah seluruh pasien diabetes melitus rawat jalan yang menjalani pemeriksaan kadar glukosa darah puasa di Poli Penyakit Dalam Rumah Sakit Islam Jakarta bulan Juli tahun 2008. Sampel adalah bagian dari populasi yang dipilih dengan cara sampling purposive dengan criteria inklusi dinyatakan sebagai pasien diabetes melitus tipe 2 oleh dokter, tanpa komplikasi, bersedia menjadi sampel dalam penelitian ini, menjalani pemeriksaan kadar glukosa darah puasa pada saat dilaksanakan penelitian. Besar Sampel yang dipakai untuk penelitian ini minimal sebanyak 49 orang.

$$
\begin{aligned}
& \mathrm{n}=\frac{\mathrm{N}}{1+\mathrm{N}(\mathrm{d} 2)} \\
& \text { Dimana : } \\
& \mathrm{N}=\text { Populasi (rerata } 3 \text { bulan terakhir) } \\
& \mathrm{n}=\text { Besar sampel } \\
& \mathrm{d}=\text { Tingkat kepercayaan }(0,05) \\
& \text { (Notoatmodjo, 1996) }
\end{aligned}
$$

Pengetahuan gizi diambil dengan metode wawancara menggunakan kuesioner. Diukur berdasarkan indikator pengertian penyakit diabetes, prinsip syarat diet penyakit diabetes, penukar bahan makanan untuk penyakit diabetes dan aktivitas/olahraga. Pada kuesioner tersebut akan diberikan skor 1 untuk jawaban yang benar dan 0 untuk jawaban yang salah pada masing - masing pertanyaan yang ada. Selanjutnya skor jawaban dibagi dengan jumlah soal lalu dikali dengan 100. Kurang, jika nilai yang diperoleh < median - standar deviasi Cukup, jika nilai yang diperoleh antara median + standar deviasi Baik, jika nilai yang diperoleh $\geq$ median + standar deviasi.

Sikap diambil dengan metode wawancara menggunakan kuesioner. Diukur berdasarkan indikator pemeriksaan penyakit diabetes, aktifitas/olahraga, kesadaran diet, bahan makanan dan jumlah porsi. Penilaiannya menggunakan skala likert yaitu sangat setuju, setuju, tidak setuju dan sangat tidak setuju dengan pertanyaan positif dan negatif, kemudian memberikan skor 4,3,2,1 untuk pernyataan positif dan 1,2,3,4 untuk pernyataan negatif, lalu dijumlah dan dibuat median kelompok. Selanjutnya dikategorikan menjadi kurang, jika nilai yang diperoleh $<$ median standar deviasi Cukup, jika nilai yang diperoleh antara median + standar deviasi Baik, jika nilai yang diperoleh $\geq$ median + standar deviasi

Tindakan diambil dengan metode wawancara menggunakan kuesioner. Diukur berdasarkan indikator pemilihan makanan/minuman, kebiasaan makan, jadwal makan, aktifitas/olahraga dan bahan makanan 
penukar. Pengamatan dilakukan secara tidak langsung dengan menggunakan kuesioner. Penilaian kuesioner dihitung dengan memberi skor 3,2,1 untuk jawaban a, b, c secara acak pada setiap pertanyaan. Selanjutnya dikategorikan menjadi Kurang, jika nilai yang diperoleh < median - standar deviasi Cukup, jika nilai yang diperoleh antara median + standar deviasi Baik, jika nilai yang diperoleh $\geq$ median + standar deviasi

Kadar Glukosa Darah Puasa (GDP) merupakan sebuah parameter yang menggambarkan konsentrasi glukosa di dalam plasma darah yang diukur pada subyek yang berpuasa selama 8-12 jam. Kadar GDP diukur dengan menggunakan metode enzymatic colorimetric. Hasil kadar glukosa darah dalam satuan $\mathrm{mg} / \mathrm{dL}$.

\section{HASIL PENELITIAN}

\section{Karakteristik Responden}

Sampel yang diambil sebanyak 50 responden. Sampel merupakan pasien diabetes melitus yang datang ke poli penyakit dalam di Rumah Sakit Islam Jakarta dalam waktu pengambilan data dilakukan. Berikut ini adalah karakteristik responden meliputi jenis kelamin, usia, pendidikan, pekerjaan, riwayat keluarga dan status gizi responden yang disajikan dalam tabel 2 .

Tabel 2. Distribusi Karakteristik Responden Di Rumah Sakit Islam Jakarta

\begin{tabular}{cllcc}
\hline No & Karakteristik & Kategori & n & $\%$ \\
\hline 1 & Jenis Kelamin & $\bullet$ Pria & 27 & 54 \\
& & $\bullet$ Wanita & 23 & 46 \\
\hline 2 & Usia & $\bullet \leq 40$ tahun & 5 & 10 \\
& & $\bullet>40$ tahun & 45 & 90 \\
\hline 3 & Pendidikan & $\bullet$ SD & 6 & 12 \\
& & $\bullet$ SMP & 10 & 20 \\
& & $\bullet$ SMA & 20 & 40 \\
& & $\bullet$ Akademi / PT & 14 & 28 \\
\hline 4 & Riwayat Keluarga & $\bullet$ Terpapar DM & 21 & 42 \\
& & $\bullet$ Tidak terpapar & 29 & 58 \\
\hline 5 & Status Gizi & $\bullet$ Normal & 15 & 30 \\
& & $\bullet$ Lebih & 35 & 70 \\
\hline
\end{tabular}

Berdasarkan tabel 2 diatas, diketahui bahwa responden dengan jenis kelamin pria dan wanita hampir sebanding jumlahnya, dimana responden pria berjumlah 27 orang (54\%) dengan usia diatas 40 tahun berjumlah 45 orang (90\%) dengan jumlah yang berpendidikan SMA 20 orang (40\%). Sejumlah 29 orang (58\%) tidak mempunyai riwayat diabetes dalam keluarganya. Sedangkan yang memiliki status gizi lebih 35 orang $(70 \%)$.

\section{Hubungan Pengetahuan Gizi dengan Kadar GLukosa Darah}

Tabel 3. Rerata Glukosa Darah Responden Menurut Pengetahuan Gizi Di Rumah Sakit Islam Jakarta

\begin{tabular}{|c|c|c|c|c|c|c|}
\hline Variabel & $\mathbf{n}$ & $\begin{array}{c}\text { Mean } \\
\text { Glukosa } \\
\text { Darah }\end{array}$ & $\begin{array}{c}\text { SD } \\
\text { Glukosa } \\
\text { Darah }\end{array}$ & $\begin{array}{c}95 \% \text { CI } \\
\text { Glukosa Darah }\end{array}$ & $\mathbf{F}$ & $\begin{array}{c}P \\
\text { value }\end{array}$ \\
\hline \multicolumn{7}{|l|}{ Pengetahuan } \\
\hline - Kurang & 12 & 188.25 & 63.71 & $147.77-228.73$ & 4,448 & 0.017 \\
\hline - Cukup & 34 & 145.62 & 52.91 & $127.16-164.08$ & & \\
\hline - Baik & 4 & 104.50 & 19.91 & $72.82-136.18$ & & \\
\hline
\end{tabular}

Rerata kadar glukosa darah pada responden yang memiliki pengetahuan kurang adalah 188.25 $\mathrm{gr} / \mathrm{ml}$ dengan standar deviasi $63.71 \mathrm{gr} / \mathrm{ml}$. Hasil uji statistik terdapat nilai $\mathrm{p}=0.017$, berarti pada alpha $5 \%$ dapat disimpulkan ada perbedaan bermakna rerata kadar glukosa darah diantara ketiga tingkat pengetahuan. Analisis lebih lanjut membuktikan bahwa kelompok yang berbeda signifikan adalah pengetahuan kurang dengan pengetahuan cukup, pengetahuan kurang dengan pengetahuan baik dan pengetahuan cukup dengan pengetahuan kurang. 


\section{Hubungan Sikap dengan Kadar GLukosa Darah}

Tabel 4. Rerata Glukosa Darah Responden Menurut Sikap Di Rumah Sakit Islam Jakarta

\begin{tabular}{lcccccc}
\hline Variabel & n & $\begin{array}{c}\text { Mean } \\
\text { Glukosa } \\
\text { Darah }\end{array}$ & $\begin{array}{c}\text { SD } \\
\text { Glukosa } \\
\text { Darah }\end{array}$ & $\begin{array}{c}\text { 95 \% CI } \\
\text { Glukosa Darah }\end{array}$ & F & P value \\
\hline Sikap & & & & & & \\
$-\quad$ Kurang & 12 & 181.79 & 71.98 & $140.23-223.35$ & 3,930 & 0.026 \\
$-\quad$ Cukup & 26 & 149.81 & 50.14 & $129.56-170.06$ & & \\
$-\quad$ Baik & 10 & 152.56 & 34.36 & $94.22-143.38$ & & \\
\hline
\end{tabular}

Rerata kadar glukosa darah pada responden yang memiliki sikap rendah adalah $181.79 \mathrm{gr} / \mathrm{ml}$ dengan standar deviasi $71.98 \mathrm{gr} / \mathrm{ml}$. Hasil uji statistik terdapat nilai $\mathrm{p}=0.026$, berarti pada alpha $5 \%$ dapat disimpulkan ada perbedaan bermakna rerata kadar glukosa darah diantara ketiga tingkatan sikap. Analisis lebih lanjut membuktikan bahwa kelompok yang berbeda signifikan adalah sikap kurang dengan sikap baik.

\section{Hubungan Tindakan dengan Kadar GLukosa Darah Puasa}

Tabel 5. Rerata Glukosa Darah Responden Menurut Tindakan Di Rumah Sakit Islam Jakarta Tahun 2008

\begin{tabular}{lcccccc}
\hline Variabel & n & $\begin{array}{c}\text { Mean } \\
\text { Glukosa } \\
\text { Darah }\end{array}$ & $\begin{array}{c}\text { SD } \\
\text { Glukosa } \\
\text { Darah }\end{array}$ & $\begin{array}{c}\text { 95 \% CI } \\
\text { Glukosa Darah }\end{array}$ & F & P value \\
\hline Tindakan & & & & & & \\
- Kurang & 8 & 172.13 & 63.52 & $119.02-225.23$ & 3,427 & 0.041 \\
- Cukup & 33 & 159.42 & 58.49 & $138.68-180.17$ & & \\
\hline
\end{tabular}

Rerata kadar glukosa darah pada responden yang memiliki pengetahuan rendah adalah 172.13 $\mathrm{gr} / \mathrm{ml}$ dengan standar deviasi $63.52 \mathrm{gr} / \mathrm{ml}$. Hasil uji statistik terdapat nilai $\mathrm{p}=0.041$, berarti pada alpha $5 \%$ dapat disimpulkan ada perbedaan bermakna rerata kadar glukosa darah diantara ketiga tingkatan tindakan. Analisis lebih lanjut membuktikan bahwa tidak ada kelompok yang berbeda secara signifikan.

\section{PEMBAHASAN}

Indeks Massa Tubuh (IMT) dan resiko penyakit diabetes memiliki hubungan linier, bertambahnya IMT akan meningkatkan resiko diabetes. Sebuah penelitian di Amerika Serikat yang dilakukan kepada 11.400 responden perempuan menunjukkan bahwa mereka yang memiliki IMT antara $25-26,9 \mathrm{~kg} / \mathrm{m}^{2}$. Penderita diabetes melitus tipe 2 delapan kali lebih tinggi dari pada responden dengan IMT $<22 \mathrm{~kg} / \mathrm{m}^{2}$. Resiko tersebut meningkat menjadi 40 kali bila IMT > 31 $\mathrm{kg} / \mathrm{m}^{2} .{ }^{1}$ Penelitian di Yogyakarta pada diabetes tipe 2 dengan status gizi yang gemuk sebesar $40 \%$, normal $37.5 \%$ dan pasien yang kurus hanya $12.5 \%$. Hampir $80 \%$ penderita diabetes pada usia lanjut mempunyai berat badan berlebih. Orang yang kegemukan tidak dapat merespon insulin dengan baik karena pada orang - orang yang gemuk yang kebutuhan insulinnya akan meningkat sebagai akibat dari pembesaran sel - sel lemak dalam tubuh. ${ }^{8}$

Pengetahuan gizi responden diketahui berdasarkan skoring pada setiap pertanyaan yang diberikan kepada responden. Pertanyaan yang diberikan meliputi penyakit diabetes, prinsip dan syarat diet, bahan makanan penukar dan aktivitas / olahraga. Rerata nilai pengetahuan gizi responden adalah 62,65 dengan nilai terendah 40 dan nilai tertinggi 86,66.

Dari setiap pertanyaan, yang paling sedikit kesalahannya adalah prinsip dan syarat diet. Hal ini menandakan bahwa sebagian besar responden sudah melakukan suatu penginderaan terhadap prinsip dan syarat diet bagi penderita diabetes. Berikut ini penjabaran dari masing - masing pertanyaan pengetahuan gizi.

Pertanyaan tentang penyakit diabetes terdiri dari 5 pertanyaan. Dari 50 responden diketahui rerata 29 responden menjawab benar. Terdapat dua buah pertanyaan mengenai hipoglikemi, Hipoglikemi adalah suatu keadaan klinis gangguan saraf yang disebabkan oleh penurunan gula darah. Tanda - tanda hipoglikemi mulai timbul bila glukosa darah $<50 \mathrm{mg} / \mathrm{dl}$, meskipun reaksi hipoglikemia bisa didapatkan pada kadar glukosa darah yang lebih tinggi. Tanda klinis dari hipoglikem sangat bervariasi pada setiap orang. Salah satunya pada stadium gangguan otak ringan yaitu lemah, lesu, sulit bicara, kesulitan menghitung 
sederhana. Adapun pertanyaan nomor 3 tentang hiperglikemi. Tanda khas dari hiperglikemi adalah kesadaran menurun disertai dehidrasi berat. Gejala ringannya adalah kesemutan dan baal pada ujung ujung saraf. ${ }^{6}$

Pada pertanyaan ditanyakan mengenai hormon yang terganggu pada diabetisi. Insulin dikeluarkan oleh sel beta yang terdapat pada kelenjar pankreas. Insulin diartikan sebagai pintu masuknya glukosa ke dalam sel, untuk kemudian diubah menjadi tenaga. Bila insulin tidak optimal kerjanya maka glukosa tidak dapat masuk sil dengan akibat glukosa akan tetap berada di pembuluh darah yang artinya kadarnya di dalam darah meningkat. ${ }^{6}$

Insulin dikeluarkan oleh sel beta yang terdapat pada kelenjar pankreas. Insulin diartikan sebagai pintu masuknya glukosa ke dalam sel, untuk kemudian diubah menjadi tenaga. Bila insulin tidak optimal kerjanya maka glukosa tidak dapat masuk sil dengan akibat glukosa akan tetap berada di pembuluh darah yang artinya kadarnya di dalam darah meningkat. ${ }^{6}$

Sedangkan istilah diabetes melitus disinggung melalui satu pertanyaan. Digambarkan adanya penyakit dengan tanda - tanda banyak kencing. Cendekiawan India dan China juga menemukan penyakit ini, dengan gejala yang sama malahan urinnya terasa manis. Willis melukiskan urin tadi seperti dicampur madu dan gula. Oleh karena itu ditambahkan nama penyakit itu dengan tambahan kata melitus (madu). Diabetes melitus disebut juga kencing manis. ${ }^{6}$

Pertanyaan tentang penyakit diabetes terdiri dari 4 pertanyaan. Dari 50 responden diketahui rerata 34,3 orang menjawab benar. Pertanyaan tentang prinsip dan syarat diet pada diabetisi terdiri dari empat pertanyaan. Berikut pembahasan pertanyaan tentang penyakit diabetes.

Tujuan terapi gizi adalah membantu diabetisi untuk memperbaiki kebiasaan makan dan olah raga untuk mendapatkan kontrol metabolik yang lebih baik dan mempertahankan kadar glukosa darah mendekati normal. ${ }^{6}$

Frekuensi makan (waktu), jenis dan jumlahnya, perencanaan makan adalah penting untuk mencegah hiperglikemi, hipoglikemi dan mempertahankan keseimbangan metabolik. Konsisten dalam hal asupan makanan adalah sangat penting pada pengobatan diabetes. Total asupan energi sehari secara tetap paling sedikit 3 kali makan, satu sampai dua kali snack antara makan dan sebelum tidur. ${ }^{6}$

Salah satu syarat diet penyakit diabetes melitus adalah penggunaan gula murni dalam minuman atau makanan tidak diperbolehkan kecuali dalam jumlah sedikit sebagai bumbu. Bila kadar glukosa darah sudah terkendali, diperbolehkan mengkonsumsi gula murni sampai 5\% dari kebutuhan energi total. ${ }^{9}$ Bagi orang dengan diabetes yang memerlukan gula, dalam penggunaannya kalori gula diperhitungkan sebagai bagian dari perencanaan makan. Satu sendok makan gula dapat menggantikan 1 penukar buah (misalnya 1 buah pisang). ${ }^{6}$

Pertanyaan tentang penyakit diabetes terdiri dari 5 pertanyaan. Dari 50 responden diketahui rerata 26,2 orang menjawab benar. Pertanyaan tentang bahan makanan penukar pada diabetisi terdiri dari lima pertanyaan.

Bahan makanan sumber karbohidrat seperti beras dapat digantikan dengan bahan makanan sumber karbohidrat lainnya seperti kentang, roti, ubi, singkong dan lainnya. Satu penukar karbohidrat mengandung 175 kalori. Satu penukar nasi dan bayam masing masing sebanyak $3 / 4$ gelas belimbing dan 1 gelas belimbing. ${ }^{6}$

Pertanyaan tentang penyakit diabetes terdiri dari 1 pertanyaan. Dari 50 responden diketahui 23 orang menjawab benar. Pertanyaan tentang aktivitas / olahraga pada diabetisi terdiri dari lima pertanyaan. Berikut pembahasan pertanyaan tentang penyakit diabetes.

Prinsip olahraga pada diabetisi sama dengan prinsip olahraga secara umum, yaitu memenuhi hal berikut ini : Frekuensi, jumlah olahraga perminggu sebaiknya dilakukan secara teratur $3-5$ kali perminggu ; Intensitas, ringan dan sedang yaitu 60\% - 70\% MHR (Maximum Heart Rate) ; Time (durasi), 30 - 60 menit dan tipe (jenis) olahraga endurans (aerobik) untuk meningkatkan kemampuan kardiorespirasi seperti jalan, jogging, berenang dan bersepeda. ${ }^{6}$

Berdasarkan tabel 7 diatas, dari 50 responden yang diambil, 14 orang (28\%) memiliki sikap kurang, 26 orang (52\%) cukup dan 10 orang (10\%) baik. Sikap responden diketahui dengan memberikan skoring $(4,3,2,1)$ pada setiap pernyataan sikap yang diberikan kepada responden. Pernyataan yang diberikan meliputi penyakit diabetes, aktifitas / olah raga, kesadaran diet, bahan makanan dan jumlah porsi. Rerata total nilai sikap responden adalah 45,74 dengan total nilai terendah 40 dan total nilai tertinggi 52 .

Sikap adalah reaksi atau respon seseorang yang masih tertutup terhadap suatu stimulus atau objek. Sikap tidak dapat langsung dilihat, tetapi hanya dapat ditafsirkan terlebih dahulu dari perilaku yang tertutup. Sikap belum merupakan suatu tindakan atau perilaku. Sikap belum merupakan suatu tindakan atau aktivitas, akan tetapi adalah merupakan "pre-disposisi tindakan atau perilaku. Sikap itu masih merupakan reaksi tertutup, bukan merupakan reaksi tingkah laku yang terbuka. ${ }^{7}$

Dari setiap pernyataan, yang paling banyak jumlah nilainya adalah olahraga dan kesadaran berdiet. Hal ini menandakan bahwa sudah ada suatu reaksi tingkah laku yang tertutup dari responden mengenai pentingnya olahraga dan berdiet terhadap penyakitnya. 
Berikut ini uraian dari masing - masing pernyataan sikap.

Pernyataan sikap tentang penyakit diabetes terdiri dari 1 pernyataan positif dan 1 pernyataan negatif. Dari 50 responden diketahui 45 orang menjawab setuju pada pernyataan positif dan untuk pernyataan negatif 42 orang menyatakan setuju.

Pada pernyataan pertama menyinggung tentang anjuran kontrol kadar glukosa darah pada diabetisi. Pemantauan kendali glisemik diabetes melitus merupakan bagian yang tak terpisahkan dari pengelolaan diabetes melitus. Pemantauan kadar glukosa darah sendiri sangat bermanfaat pada pasien DM tipe 1 dan DM tipe 2. Pada DM tipe 2, pemeriksaan kadar glukosa darah 1 kali sehari sebelum sarapan pagi atau sebelum tidar sudah cukup. Bila kendali glisemiknya lebih stabil, 1 kali pemeriksaan seminggu sudah cukup. ${ }^{6}$

Pernyataan berikutnya yaitu tentang hipoglikemia. Hipoglikemia adalah suatu keadaan klinis gangguan saraf yang disebabkan oleh penurunan gula darah. Tanda - tanda hipoglikemi mulai timbul bila glukosa darah $<50 \mathrm{mg} / \mathrm{dl}$, meskipun reaksi hipoglikemia bisa didapatkan pada kadar glukosa darah yang lebih tinggi. Tanda klinis dari hipoglikem sangat bervariasi pada setiap orang. Salah satunya pada stadium gangguan otak ringan yaitu lemah, lesu, sulit bicara, kesulitan menghitung sederhana. ${ }^{6}$

Pernyataan sikap tentang aktivitas / olahraga terdiri dari 1 pernyataan positif dan 1 pernyataan negatif. Dari 50 responden diketahui 47 orang menjawab setuju pada pernyataan positif dan untuk pernyataan negatif 46 orang menyatakan setuju.

Terdapat dua pernyatan sikap tentang aktifitas / olahraga. Para ahli percaya bahwa olahraga merupakan salah satu cara penatalaksanaan DM, meskipun penelitian tentang manfaat olahraga bagi diabetisi masih kurang. Dari data yang diperoleh seperti suatu penelitian yang dilakukan di USA ditemukan bahwa resiko menderita penyakit DM lebih rendah pada kelompok yang berolah raga 5 kali seminggu dibandingkan dengan kelompok yang berolahraga 1 kali seminggu. ${ }^{6}$

Prinsip olahraga pada diabetisi sama dengan prinsip olahraga secara umum, yaitu memenuhi hal berikut ini : Frekuensi, jumlah olahraga perminggu sebaiknya dilakukan secara teratur $3-5$ kali perminggu ; Intensitas, ringan dan sedang yaitu $60 \%-70 \%$ MHR (Maximum Heart Rate) ; Time (durasi), 30 - 60 menit dan tipe (jenis) olahraga endurans (aerobik) untuk meningkatkan kemampuan kardiorespirasi seperti jalan, jogging, berenang dan bersepeda. ${ }^{6}$

Pernyataan sikap tentang kesadaran diet terdiri dari 2 pernyataan positif dan 2 pernyataan negatif. Dari 50 responden diketahui rerata 47 orang menjawab setuju pada pernyataan positif dan untuk pernyataan negatif rerata 16 orang menyatakan setuju.

Pernyataan tentang pentingnya diet kontrol glukosa darah, kepatuhan pasien terhadap prinsip gizi dan perencanaan makan merupakan salah satu kendala pada pelayanan diabetes, padahal terapi gizi merupakan komponen utama keberhasilan penatalaksaan diabetes. Tujuan terapi gizi adalah membantu diabetisi untuk memperbaiki kebiasaan makan dan olah raga untuk mendapatkan kontrol metabolik yang lebih baik dan mempertahankan kadar glukosa darah mendekati normal. ${ }^{6}$

Meskipun sudah majunya riset di bidang pengobatan diabetes dengan ditemukannya berbagai jenis insulin dan obat oral yang mutakhir, diet masih tetap merupakan pengobatan yang utama pada penalaksaan diabetes, terutama pada DM tipe 2. Peran diet jelas sekali terutama pada pasien gemuk yang toleransi glukosanya jelas menjadi normal dengan menurunnya berat badan. ${ }^{6}$

Terdapat dua pernyataan sikap tentang frekuensi makan. Makanan dengan porsi kecil dan sering dapat mengendalikan kadar glukosa darah. Makanan dengan sejumlah kalori yang terhitung dengan komposisi yang sesuai dibagi dalam 3 porsi utama untuk makan pagi, siang dan sore serta $2-3$ porsi makanan ringan diantaranya. Almatsier (2004) menambahkan, salah satu syarat diet diabetes adalah makanan dibagi dalam 3 porsi utama, pagi (20\%), siang (30\%) dan sore $(25 \%)$, untuk snack $2-3$ kali (masing - masing $10-15 \%$ ). ${ }^{6}$

Pernyataan sikap tentang kesadaran diet terdiri dari 3 pernyataan positif dan 2 pernyataan negatif. Dari 50 responden diketahui rerata 45.33 orang menjawab setuju pada pernyataan positif dan untuk pernyataan negatif rerata 18 orang menyatakan setuju.

Pada pernyataan sikap tentang serat, rerata asupan serat dalam makanan sehari - hari yang dianjurkan yaitu 25 - 35 gram, diutamakan serat makanan yang larut seperti yang terdapat dalam kacang - kacangan, kentang, jagung, oat, wortel, bayam, buncis dan buah - buahan yang dimakan dengan kulitnya. ${ }^{9}$ Mengkonsumsi bahan makanan sumber serat seperti : serealia, brown bread, kacang kacangan, tempe, buah dan sayuran segar dapat meningkatkan kesehatan secara umum. ${ }^{6}$

Pada pernyataan tentang gula murni, penggunaan gula murni dalam minuman atau makanan tidak diperbolehkan kecuali dalam jumlah sedikit sebagai bumbu. Tetapi bila kadar glukosa darah sudah terkendali, diperbolehkan mengkonsumsi gula murni sampai 5\% dari kebutuhan energi total. ${ }^{9}$ Sedikit gula untuk bumbu diperbolehkan. Anjuran konsumsi gula untuk orang Indonesia baik yang normal maupun pasien diabetes yang memerlukan adalah tidak lebih dari 5\% total kalori (3 - 4 sendok makan) sehari. Bagi pasien diabetes yang memerlukan gula, kalori gula 
diperhitungkan sebagai bagian dari perencanaan makan. ${ }^{6}$

Pernyataan tentang indeks glikemik, beberapa jenis beras yaitu, beras ketan, beras merah, beras pera dan beras pulen pada setiap 100 kal masing - masing, didapatkan hasil ternyata yang yang paling tinggi indeks glikemiknya adalah beras ketan $(87.06 \%)$, dilanjutkan beras merah $(70.20 \%)$, beras pera $(52.84 \%)$ dan beras pulen $(51.80 \%){ }^{5}$

Untuk individu yang mempunyai kadar lipid normal dan dapat mempertahankan berat badan yang memadai dianjurkan tidak lebih dari $30 \%$ asupan energi dari lemak total dan $<10 \%$ energi dari lemak jenuh. Anjuran untuk asupan lemak di Indonesia adalah $20-25 \%$ energi. Namun demikian, pada individu yang kegemukan peningkatan asupan lemak dapat memperburuk keadaannya, dan nantinya akan menggangu kadar glukosa darah. ${ }^{6}$ Diet tinggi karbohidrat dan rendah lemak sangat baik untuk pasien diabetes karena dapat mengurangi resiko aterosklerosis. Dianjurkan baik oleh ADA (American Diabetes Association) maupun EASD (European Association for Study of Diabetes) bahwa asupan lemak jangan lebih dari $30 \%$ dan kolesterol kurang dari $300 \mathrm{mg} /$ hari. ${ }^{10}$

Pada keadaan apapun pengobatan yang paling baik adalah pencegahan. Makan tepat waktunya dan tepat jumlah kalori adalah pokok utama pencegahan. Bila hipoglikemi telah terjadi maka pengobatan harus segera dilakukan terutama gangguan terhadap otak, organ yang paling sensitif terhadap penurunan glukosa darah. Pemberian gula murni \pm 30 gram $(2 \mathrm{sdm})$ atau sirup, permen dan makanan yang mengandung hidrat arang sederhana. Setelah itu periksa kadar glukosa darah sewaktu. ${ }^{6}$

Pernyataan sikap tentang kesadaran diet terdiri dari 2 pernyataan negatif. Dari 50 responden diketahui rerata 24 orang menjawab setuju. Salah satu syarat diet diabetes adalah makanan dibagi dalam 3 porsi utama, pagi $(20 \%)$, siang $(30 \%)$ dan sore $(25 \%)$, untuk snack $2-3$ kali (masing - masing $10-15 \%){ }^{9}$

Untuk pernyataan tentang pemanis buatan, pada gula alternatif seperti sorbitol, mannitol dan xylitol menghasilkan indeks glikemik lebih rendah dari pada sukrosa dan karbohidrat lain. Penggunaan pemanis tersebut secara berlebihan mempunyai pengaruh laksatif. Secara umum pemanis dapat digunakan secukupnya dalam minuman, sedangkan bila digunakan dalam kue perlu diperhitungkan maksimal penggunaan per porsi. ${ }^{6}$

Berdasarkan tabel 8 diatas, dari 50 responden yang diambil, 9 orang (18\%) memiliki sikap kurang, 33 orang $(66 \%)$ cukup dan 8 orang (16\%) baik. Tindakan responden diketahui dengan memberikan skoring $(3,2,1)$ pada setiap pertanyaan tindakan yang diberikan kepada responden, kemudian menjumlahkannya.
Pertanyaan yang diberikan meliputi pemilihan makanan dan minuman, kebiasaan makan, jadwal makan, aktivitas/olahraga dan bahan makanan penukar. Rerata total nilai sikap responden adalah 33,34 dengan total nilai terendah 22 dan total nilai tertinggi 43.

Dari setiap pertanyaan, yang paling banyak jumlah nilainya adalah pemilihan makanan dan minuman. Hal ini menandakan bahwa sudah ada suatu perbuatan nyata dari responden dalam hal yang berkaitan dengan pemilihan makanan dan minuman. Sedangkan yang paling sedikit adalah pertanyaan tentang aktivitas/olahraga. Sikap seseorang akan menjadi perbuatan nyata diperlukan faktor pendukung yang memungkinkan, antara lain adalah fasilitas. ${ }^{7}$

Ada banyak teori tentang perubahan perilaku, salah satunya Teori Stimulus - Organisme - Respon (SOR). proses perubahan perilaku pada dasarnya adalah sama dengan proses belajar. ${ }^{7}$ Dari 50 responden yang didapat, rerata kadar glukosa darah puasanya adalah $152.56 \mathrm{mg} / \mathrm{dL}$. Dengan kadar terendah adalah $60 \mathrm{mg} / \mathrm{dL}$ dan tertinggi adalah $295 \mathrm{mg} / \mathrm{dL}$. Hasil ini tidak jauh berbeda dengan beberapa penelitian dimana jumlah responden yang diambil sebanyak 38 responden dan jumlah yang memiliki kategori buruk adalah 21 responden $(55.26 \%) .{ }^{11,12}$

\section{SIMPULAN}

Ada perbedaan bermakna kadar glukosa darah berdasarkan pengetahuan gizi, sikap dan perilaku terhadap pasien dengan diabetes mellitus tipe 2 di Rumah Sakit Islam Jakarta

\section{SARAN}

1. Meningkatkan penyuluhan atau konsultasi gizi kepada pasien diabetes melitus, baik secara kualitas maupun kuantitas, untuk dapat mengubah perilaku pasien.

2. Perlu adanya penelitian tentang pengaruh konsultasi atau penyuluhan gizi terhadap perilaku pasien di Rumah Sakit Islam Jakarta agar mengetahui tingkat keberhasilan Dietisien dalam melaksanakan penyuluhan atau konsultasi gizi.

\section{DAFTAR PUSTAKA}

1. Rimbawan dan Albiner Siagian. 2004. Indeks Glikemik Pangan. Jakarta : Penebar Swadaya

2. Sudoyo Aru W, Bambang Setiyohadi, Idrus Alwi, Marcellus Simadibrata K, Siti Setiati, ed. Ilmu Penyakit Dalam Jilid III Edisi IV. Jakarta: Pusat Penerbitan Ilmu Penyakit Dalam Fakultas Kedokteran Universitas Indonesia. 2006.

3. Wild S, Roglic G, Green A, sicree R, King H. Global prevalence of diabetes. Estimates for the 
year 2000 and projections for 2030. Diabetes Care 2004; 27: 1218-1224.

4. Tjokroprawiro, Askandar. Hidup Sehat dan Bahagia Bersama Diabetes Melitus. Jakarta: Penerbit PT Gramedia Pustaka Utama. 2006

5. Waspadji, Sarwono dkk. 2003. "Indeks Glikemik Monosakarida, Disakarida Dan Polisakarida Murni Sebagai Bahan Makanan Sumber Karbohidrat Pada Orang Tidak Diabetes" dalam Indeks Glikemik Berbagai Makanan Indonesia. Jakarta : Balai Penerbit FKUI. Hal 1-26.

6. Soegondo, Sidartawan, Pradana Soewondo, Imam Subekti, ed. Penatalaksanaan Diabetes Melitus Terpadu. Jakarta: Balai Penerbit FKUI; 2004.

7. Notoatmodjo, Soekidjo. 1996. Ilmu Kesehatan Masyarakat Prinsip - Prinsip Dasar. Jakarta : PT Asdi Mahasatya

8. Jazilah, Paulus Wijono, Toto Sudargo. Hubungan Tingkat Pengetahuan, Sikap dan Prektik (PSP) Penderita Diabetes Mellitus Mengenai Pengelolaan Diabetes Mellitus dengan Kendali Kadar Glukosa Darah. Yogyakarta: Universitas Gajah Mada; 2003.

9. Almatsier, Sunita. Penuntun Diet Edisi Baru. Jakarta : Penerbit PT Gramedia Pustaka Utama. 2004

10. American Diabetes Association. Standards of Medical Care In Diabetes 2010. Diabetes Care. 2004; 27: 1761-73.

11. Archer SL, Greenlund KJ, Rith-Najarian S, Croft J, Casper ML. Association of Diabetes Education with Dietary Intake and Biochemical Parameters: the Inter-Tribal Health Project. Journal of the American Dietetic Association; 2002.

12. Ucik Witasari, Setyaningrum Rahmawaty, Siti Zulaekah. Hubungan Tingkat Pengetahuan, Asupan Karbohidrat Dan Serat Dengan Pengendalian Kadar Glukosa Darah Pada Penderita Diabetes Melitus Tipe 2. Jurnal Penelitian Sains \& Teknologi, Vol. 10, No. 2; 2009. 